\title{
Stability of vancomycin hydrochloride solutions in high concentration and extended time of infusion
}

\author{
MA Peterlini, APS Barbosa, M Pedreira \\ From ESICM LIVES 2015 \\ Berlin, Germany. 3-7 October 2015
}

\begin{abstract}
Introduction
Vancomycin hydrochloride is an antimicrobial commonly used and studied in the treatment of patient with healthcare-associated infections. However, there are few studies related to this drug stability during administration. In intensive care units, mainly pediatric and neonatal, the clinical conditions and specific needs of patients may require longer time of vancomycin hydrochloride infusion or concentrated solutions, different of literature recommendations of a final dilution of 2.5 to $5.0 \mathrm{mg} / \mathrm{ml}$ in one hour of infusion. There is a lack of evidences for nursing practice regarding vancomycin hydrochloride infusion in higher concentration and longer time.
\end{abstract}

\section{Objectives}

To determine the stability of vancomycin hydrochloride solutions at a concentration of $10 \mathrm{mg} / \mathrm{mL}$, according to two infusion periods.

\section{Methods}

Experimental study that simulated the nursing clinical practice of intravenous administration of vancomycin hydrochloride solutions at a concentration of $10 \mathrm{mg} / \mathrm{ml}$. The stability was determined by high-performance liquid chromatography (HPLC) and $\mathrm{pH}$ in two conditions of temperature, $22^{\circ} \mathrm{C}( \pm 1)$ and $37^{\circ} \mathrm{C}( \pm 1)$, and two exposure times, 60 and 120 minutes. The concentration and $\mathrm{pH}$ were monitored after drug reconstitution with water for injection, after dilution with sodium chloride $0.9 \%$ and after 60 and 120 minutes of infusion. The sample was collected in triplicate to $\mathrm{pH}$ analyzes, and each triplicate was analyzed by HPLC in quintuplicate to determine a final concentration. Data were analyzed by using the mean and standard deviation $(\mathrm{m} \pm \mathrm{SD})$.

\section{Results}

Of the $60 \mathrm{pH}$ analyzed values of vancomycin solutions, no substantial variations were observed (Tables 1 ). HPLC analyzes resulted in 120 measured concentrations; at $22^{\circ} \mathrm{C}( \pm 1)$ an increased concentration of $4.03 \%$ and $21.11 \%$ were identified, at 60 and 120 minutes, respectively (Table 1$)$. Solutions exposed to $37^{\circ} \mathrm{C}( \pm 1)$ resulted in an increased concentration of $4.59 \%$ in 60 minutes and a decreased concentration of $10.28 \%$ in 120 minutes (Table 1). It is important to highlight that medication preparation was accomplished in syringes and the measured initial concentrations were different than $10 \mathrm{mg} / \mathrm{mL}$.

\section{Conclusions}

Vancomycin hydrochloride solutions diluted at $10 \mathrm{mg} / \mathrm{ml}$ presented a clinically relevant alteration when infused during $120 \mathrm{~min}$, despite the analyzed temperature.

Table 1. Concentration, variation ratio and $\mathrm{pH}$

\begin{tabular}{lcccccc}
\hline \multicolumn{1}{c}{ Experimental situations } & \multicolumn{2}{c}{ Concentration $(\mathbf{m g} / \mathbf{m L})$} & Concentration variation & \multicolumn{2}{c}{$\mathbf{p H}(\mathbf{u n i t})$} \\
\hline $22^{\circ} \mathrm{C}( \pm 1) 60$ minuts & Initial & Final & $(\%)$ & Initial & Final \\
\hline $22^{\circ} \mathrm{C}( \pm 1) 120$ minuts & $9.17 \pm 0.56$ & $9.54 \pm 1.32$ & 4.03 & $3.59 \pm 0.03$ & $3.64 \pm 0.02$ \\
\hline $37^{\circ} \mathrm{C}( \pm 1) 60$ minuts & $8.43 \pm 0.57$ & $10.21 \pm 1.41$ & 21.11 & $3.63 \pm 0.05$ & $3.65 \pm 0.01$ \\
\hline $37^{\circ} \mathrm{C}( \pm 1) 120$ minuts & $9.57 \pm 0.74$ & $10.01 \pm 0.45$ & 4.59 & $3.62 \pm 0.02$ & $3.65 \pm 0.01$ \\
\hline
\end{tabular}

Federal University of São Paulo, Pediatric Nursing, São Paulo, Brazil 


\section{Grant Acknowledgment}

National Council for Scientific and Technological Development - CNPq

462183/2014-9

Published: 1 October 2015

doi:10.1186/2197-425X-3-S1-A717

Cite this article as: Peterlini et al: Stability of vancomycin hydrochloride solutions in high concentration and extended time of infusion. Intensive Care Medicine Experimental 2015 3(Suppl 1):A717.

\section{Submit your manuscript to a SpringerOpen ${ }^{\circ}$ journal and benefit from:}

- Convenient online submission

- Rigorous peer review

- Immediate publication on acceptance

- Open access: articles freely available online

- High visibility within the field

- Retaining the copyright to your article

Submit your next manuscript at $\gg$ springeropen.com 